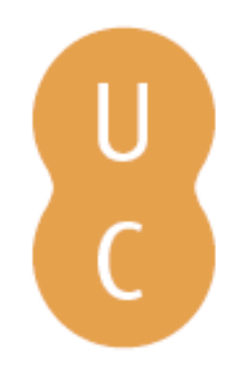

\title{
nommalina
}

\section{Impact of eutrophication on amphipods Melita palmata and Ampithoe valida in the Mondego estuary}

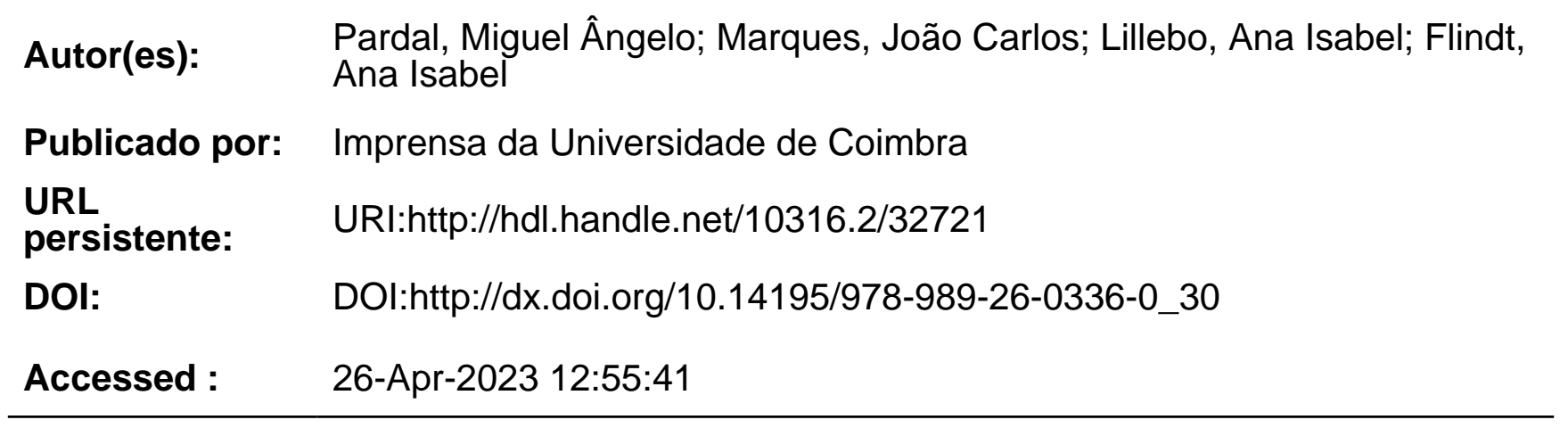

A navegação consulta e descarregamento dos títulos inseridos nas Bibliotecas Digitais UC Digitalis, UC Pombalina e UC Impactum, pressupõem a aceitação plena e sem reservas dos Termos e Condições de Uso destas Bibliotecas Digitais, disponíveis em https://digitalis.uc.pt/pt-pt/termos.

Conforme exposto nos referidos Termos e Condições de Uso, o descarregamento de títulos de acesso restrito requer uma licença válida de autorização devendo o utilizador aceder ao(s) documento(s) a partir de um endereço de IP da instituição detentora da supramencionada licença.

Ao utilizador é apenas permitido o descarregamento para uso pessoal, pelo que o emprego do(s) título(s) descarregado(s) para outro fim, designadamente comercial, carece de autorização do respetivo autor ou editor da obra.

Na medida em que todas as obras da UC Digitalis se encontram protegidas pelo Código do Direito de Autor e Direitos Conexos e demais legislação aplicável, toda a cópia, parcial ou total, deste documento, nos casos em que é legalmente admitida, deverá conter ou fazer-se acompanhar por este aviso.

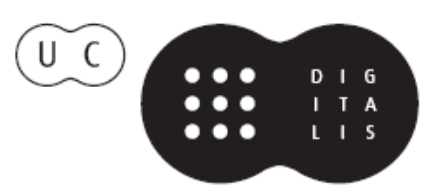


MIGUEL ÂNGELO PARDAL JOÄO CARLOS MARQUES MANUEL AUGUSTO GRAÇA Scientific Editors

\section{Aquatic Ecology of the Mondego River Basin Global Importance of Local Experience}




\author{
MIGUEL ÂNGELO PARDAL \\ JOẢO CARLOS MARQUES \\ MANUEL AUGUSTO GRAÇA \\ Scientific Editors
}

\title{
Aquatic Ecology of the Mondego River Basin Global Importance of Local Experience
}




COORDENAÇÃO EDITORIAL
Imprensa da Universidade de Coimbra
CONCEPÇÃO GRAFICA
António Barros
INFOGRAFIA
António Resende
Estimulus [design] • Coimbra
EXECUÇÃO GRAFICA
GRAFIASA
ILUSTRAÇÃO DA CAPA
P. P. Cunha e ]. Dinis
ISBN
972-8704-04-6
DEPOSITO LEGAL
I75038/02

(C) JANEIRO 2002, IMPRENSA DA UnIVERSIDADE DE COIMBRA

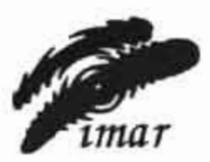

CPIMAR

imar

OBRA PUBLICADA COM O PATROCINIO DE:

IMAR - INSTITUTO DO MAR

IPIMAR - INSTITUTO DE INVESTIGAÇĀO DAS PESCAS E DO MAR 



\author{
Miguel Ângelo Pardal ' \\ João Carlos Marques ' \\ INES METELO ' \\ ANA ISABEL LILLEBO ' \\ MOGENS RENE FUINDT ${ }^{2}$
}

\title{
IMPACT OF EUTROPHICATION ON AMPHIPODS Melita palmata AND Ampithoe valida INTHE MONDEGO ESTUARY
}

\begin{abstract}
The life cycle, population dynamics and production of Ampithoe valida and Melita palmato were studied in an intertidal mudflat in central Portugal. Sampling was carried out in eutrophicated areas, where macroalgae blooms of Enteromorpha spp. usually occur from January to early summer, and also in non-eutrophicated areas characterised as Zostera noltii meadows. Both amphipod species showed a contagious distribution, and the populations densities clearly changed during the study period along the eutrophication gradient. No migratory patterns were detected between the estuary and the sea, but dispersion inside the estuary might occur in these amphipods. Both species presented a two-generation life cycle involving a short-lived fast growing summer generation ( 7 months for A volida and 4-5 months for M. palmate) and a longer-lived, slower growing generation that overwinters ( 9 months for $A$. valido and 67 months for $M$. palmoto). Along the eutrophication gradient no differences were found regarding the biology of the species. Besides these features, differences were observed between eutrophicated and non eutrophicated areas in regard to productivity.

In a certain extent, the increase of macroalgae biomass may favour these herbivorous amphipods populations, but extensive blooms affecting the whole area of distribution of these species will determine its disappearance.

This Chapter includes new information and information already published in Marine Ecology Progress Series (2000, 196:207-219).
\end{abstract}

\section{Introduction}

Eutrophication appears to be a common phenomenon in coastal waters around the world. The replacement of rooted macrophytes by opportunistic green macroalgae (Chaetomorpha, Enteromorpha and Ulva) seam to be also a major feature in these ecosystems when they suffer from organic pollution. (Hickel et al. 1993, Yeates 1993. Dijk et al. 1994. Hartog 1994, Flindt et al. 1997. Marques et al. 1997, Rafaelli et al. 1998).

i1) IMAR - Instituto do Mar, Centro Interdiscipliriar de Coimbra a/c Departamento de Zoologia. Universidade de Coimbra, 3004-517 Coimbra, Portugal

(1) Biological Institute, Southem Danish University, Odense, Campusvey S5, DK-5230, Odense M, Denmark 
In the south arm of the Mondego estuary, seasonal intertidal macroalgae blooms (mainly of Enteromorpha spp.) have been reported for several years (Marques et al. 1993a, 1993b, 1997. Pardal et al. 1993, Pardal 1998, Flindt et al. 1997. Lillebø et al. 1999. Martins et al. 200I) due to nutrient enrichment of estuarine waters (Marques et al. 1997. Pardal 1998, Martins et al. 200 I). As a consequence, Zostera noltii beds, which represent the richest habitat with regard to productivity and biodiversity, have been drastically reduced in the south arm of the estuary. presumably out competed by Enteromorpha (Rafaelli et al. 1991. Hodgkin and Hamilton 1993. Pardal 1998).

Ampithoe valida and M. polmato are grazers that can be found on rocky substrata and on muddy bottoms, often in the presence of green macroalgae or macrophytes (e.g. Zostera noltii). Both species present a wide distribution but they received little attention (Borowsky 1983. Pardal et al. 2000). Despite that there are just a few studies on the impact of macroalgae blooms on grazer amphipod species population dynamics (Drake and Arias 1995, Pardal et al. 2000), Such knowledge may definitely contribute for a better understanding of dynamic processes related with shift in primary producers a usual phenomenon in European and north America coastal waters.

\section{Materials and methods}

In the south arm macroalgal blooms of Enteromorpha spp. have been regularly observed during the last 15 years (Flindt et al. 1997, Marques et al. 1997, Pardal 1998, Lillebø et al. 1999. Pardal et al. 2000, Martins et al. 200I). This is probably a result of excessive nutrient release into the estuary, coupled with longer persistence of nutrients (nitrogen and phosphorous) in the water column. Nevertheless, such macroalgae blooms may not occur in exceptionally rainy years (e.g. year 1994) due to low salinity for long periods, as a result of the Pranto river discharge (Pardal 1998. Martins et al. 2001).

The amphipods were monitored in the Mondego estuary during 18 months, from January 1993 to June 1994. Samples were taken fortnightly at three different sites along an estuarine gradient of eutrophication in the south arm of the estuary (Fig. 1). From a Zostera nolti meadow, up to a heavily eutrophicated zone, in the inner areas of the estuary. where Enteromorpha spp. blooms have been observed during the last two decades.

Each time at each site ten cores (with a $141 \mathrm{~cm}^{2}$ ) were taken to a depth of 15 $\mathrm{cm}$ and sieved through a $500 \mu \mathrm{m}$ mesh sieve.

Amphipods were identified, counted, measured and sexed. Due to the difficulties in measuring Total body Length $\left(T_{L}\right)$ accurately in such a small organisms that are typically comma-shaped, an alternative and more accurate length was measured: The Cephalic Length (C) (measured between the extremity of the rostrum and the base of the head). So for both species an equation for $C_{1}-T_{1}$ conversion was determined $\left(T_{L}\right.$ $=-0.1355+9.4233^{*} C_{1}, n=262, r=0.965$ for A. valida and $T_{t}=-0.62503+9.877 I^{*} C_{1}$. $n=323, r=0.955$ for M. palmato). Length-weight relationships were determined for production estimates. $A$ single regression equation was determined for each species $\left(W=0.00085^{*} C^{.3631}, n=95, r=0.983\right.$ for $A$. valido and $W=0.00196^{*} C^{1.6533}, n=72$, $r=0.966$ for M. palmata ). 


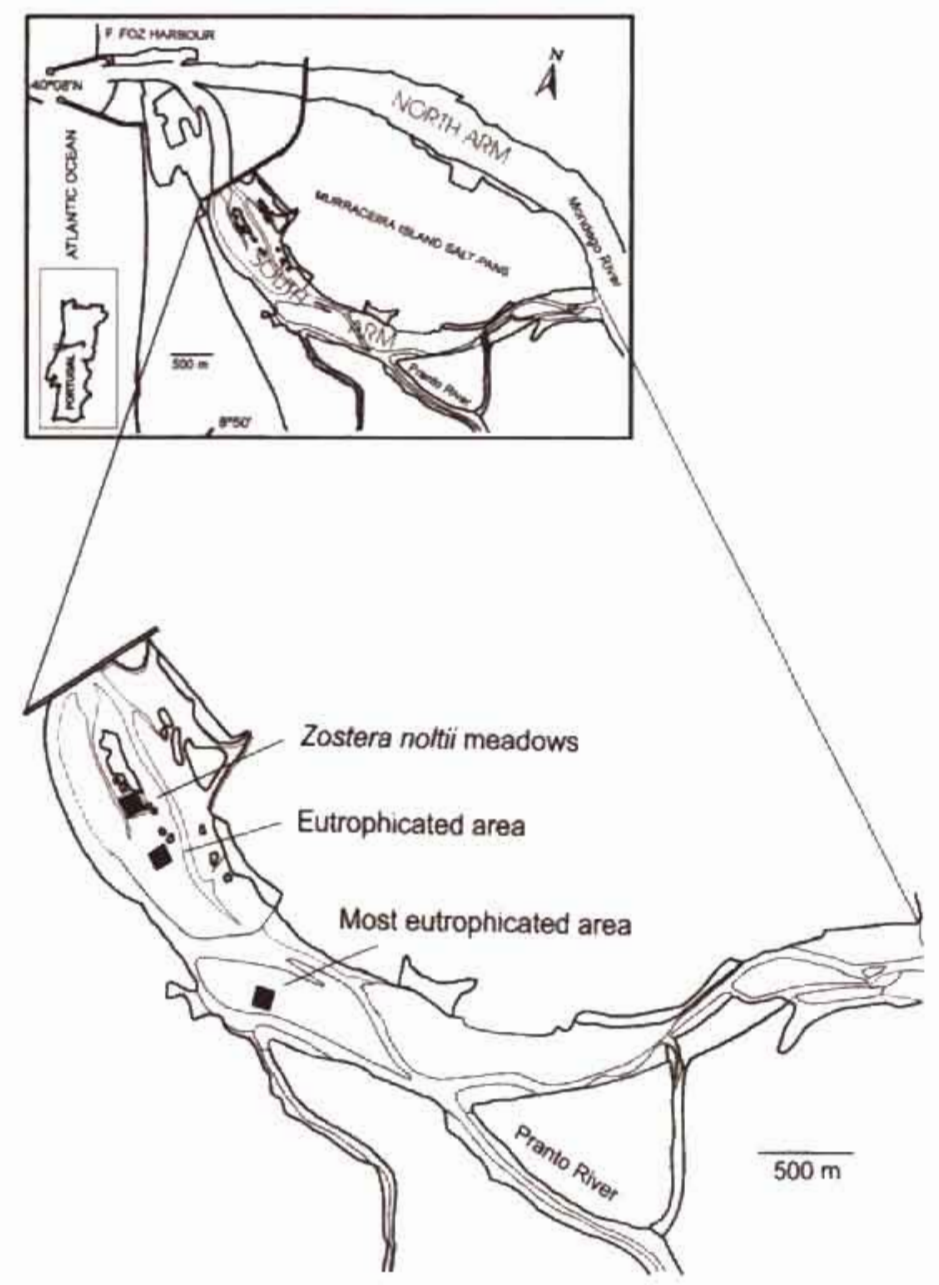

Fig. 1. Location of the sampling stations along a spatial gradient of eutrophication in the Mondego estuary.

For the determination of sex we used the same methodology described in Pardal et al. $(2000,2001)$. When broods were present, eggs were counted (to estimate the fecundity), measured and examined to determined the development stage. Taking into consideration several similar critena (Goedmakers 1981. Skadsheim 1982. Steele and Steele 1969, Marques and Nogueira 1991, Marques et al. 1994, Pardal et al. 2000) five stages were considered: a) newly laid, eggs grouped and resembling a gelatinous mass; b) eggs well separated, internally homogeneous; c) embryo comma-shape, pereopods starting to be visible; d) constriction of the comma clearly visible, appendages segmented and looking slender, eyes visible, cephalotorax orange-red; e) hatched and free juveniles.

All the statistical analysis, conceming: a) population spatial dispersion; b) multiple regression models between the density and biomass of amphipods and biomass of green 
macroalgae, salinity and water temperature; c) estimation of field growth rates; d) estimation of production (net production $(P)$ and elimination production $(E)$, were developed following the procedures and techniques explained in Pardal et al. (2000; 2001).

\section{Results}

Macrophytes and macroalgae biomass

The Zostero nolti biomass exhibited a clear seasonal variation. During autumn and winter total biomass depended essentially on the thizomes, while during spring and summer total biomass increased due to the growth of leaves (Fig. 2A).
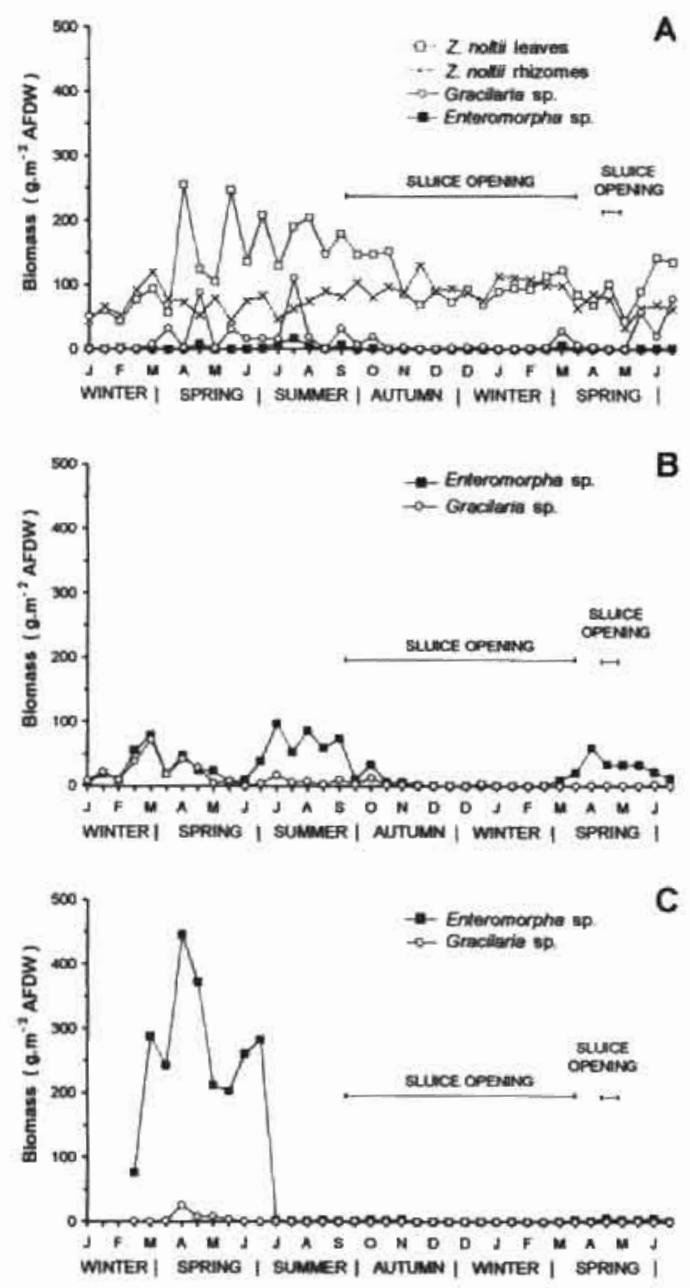

Fig. 2 Seasonal changes in plant biomass along the eutrophication gradient. (A) Zostero noltii meadows: (B) Intermediate eutrophicated area; (C) Most eutrophicated area. 
In the inner areas of the estuary that corresponds to the most eutrophicated area Enteromorpho sp. exhibited a typical spring bloom in 1993. In the end of June an algal crash occurred causing a severe impact on the macrofauna (Figs. 2, 3). In 1994 no macroalgal bloom occurred because it was a very rainy year in central Portugal which increased freshwater discharges of the Pranto river that kept salinity low. Such conditions inhibit Enteromorpha growth, since salinity was below $10 \%$ for several months.
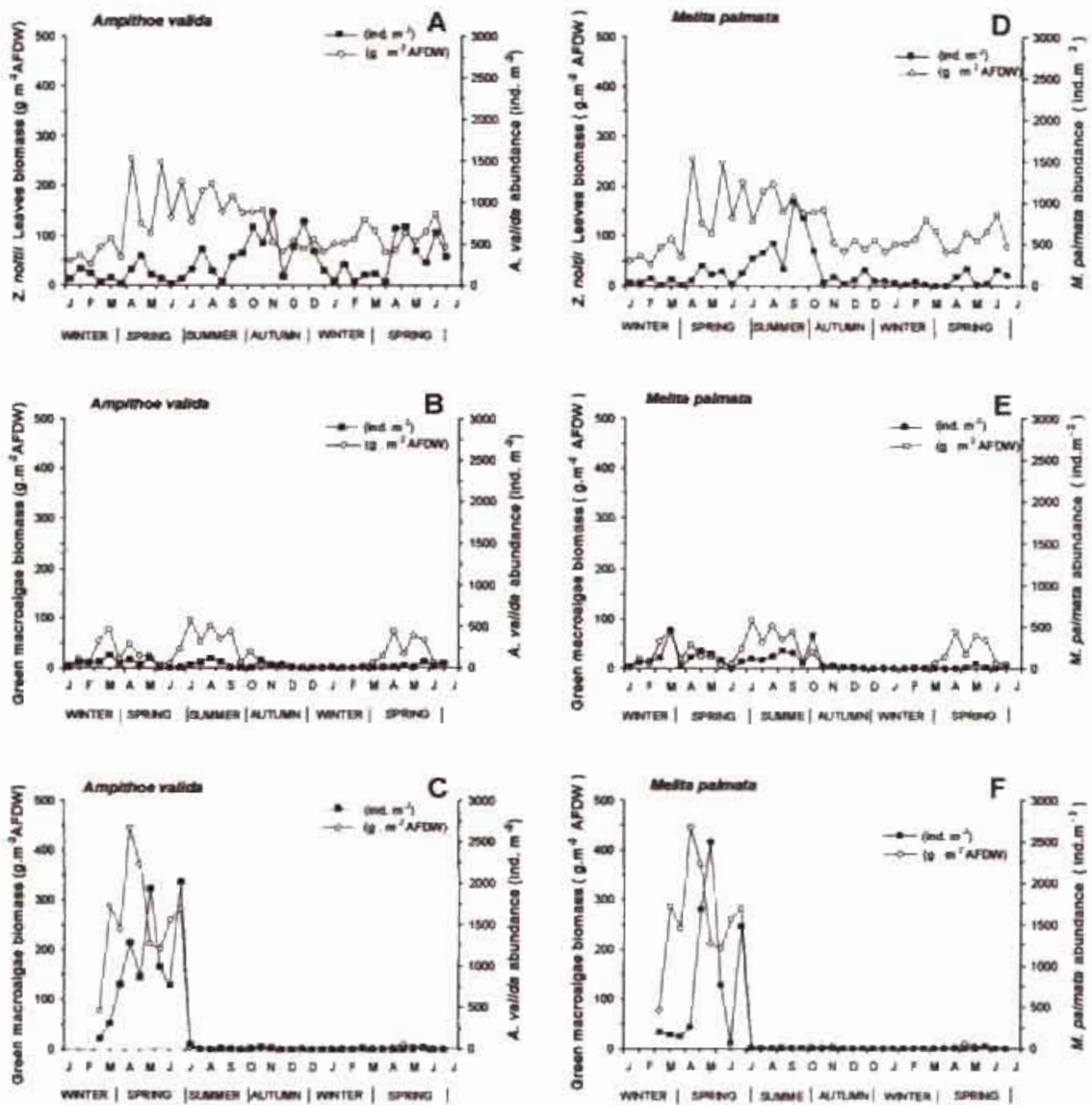

Fig. 3 Abundance of $A$. valnda and M. polmoto along the eutrophication gradient Zostero noltu meadows (A and D): Eutrophicated area ( $B$ and $E$ ): Most eutrophicated area ( $C$ and $F$ ) 
Spatial distribution and abundance

Both amphipod species showed an aggregated spatial distribution in the three study areas along the eutrophication gradient (Elliot 1977). Population density of A. valida and $M$. palmata changed throughout the period of study but the variation pattern was not the same along the eutrophication gradient (Fig. 3). In the most eutrophicated area densities were consistently higher during the algal bloom. After the algae crash density of both species declined sharply and remained low, or organisms even disappear throughout the study (Fig. 3C and 3F). In the intermediate eutrophicated area the variation in density was correlate with the variation in macroalgal biomass ( $r=0.87, \mathrm{~N}$ $=26$ for A. valida). but densities never reached so high abundances as in the previous case (Fig. 3B). With such low abundances most of the statistical analysis that we performed in the present paper were not possible in this area. At the Zostero noltii meadows, as a pattern for both species, the population density increased during summer and fall (1993) and also during spring (1994) (Fig. 3A and 3D).

Stepwise multiple regression analysis indicated that abundance (A) and biomass (B) of both amphipods in the most eutrophicated area was positively correlated with Enteromorpha sp. biomass (ENT), Grocilaria sp. biomass (Grace) and temperature of the water (TEMP):

$$
\begin{aligned}
& \text { A. valida } \\
& \ln (1+A)=0.350+1.142 \ln (1+\text { ENT }) \\
& \ln (1+B)=-0.030+0.030 \ln (1+E N T)+0.096 \ln (1+\text { Grace }) \\
& \text { M. paimato } \\
& \ln (1+A)=-4.633+0.660 \ln (1+\text { ENT }+0.248 \text { (TEMP) } \\
& \ln (1+B .)=-0.238+0.017 \ln (1+\text { ENT }+0.012 \text { (TEMP) }
\end{aligned}
$$

In the $Z$. noltii meadows only for $M$. palmata were found significant correlations between these population parameters and leaves biomass (LEA) and temperature of the water.

$$
\begin{aligned}
& \text { M. polmato } \\
& \ln (1+A)=-3,784+0,660 \ln (1+\text { LEA }) \\
& \ln (1+B)=-0,88+0,007(\text { TEMP })
\end{aligned}
$$




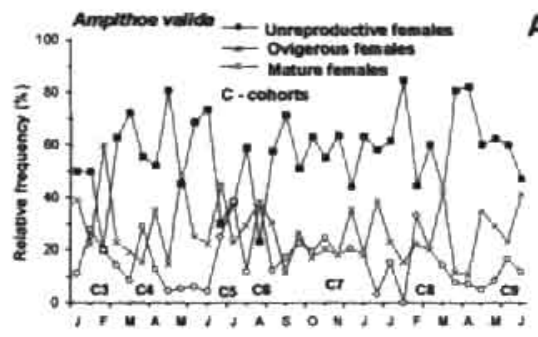

A
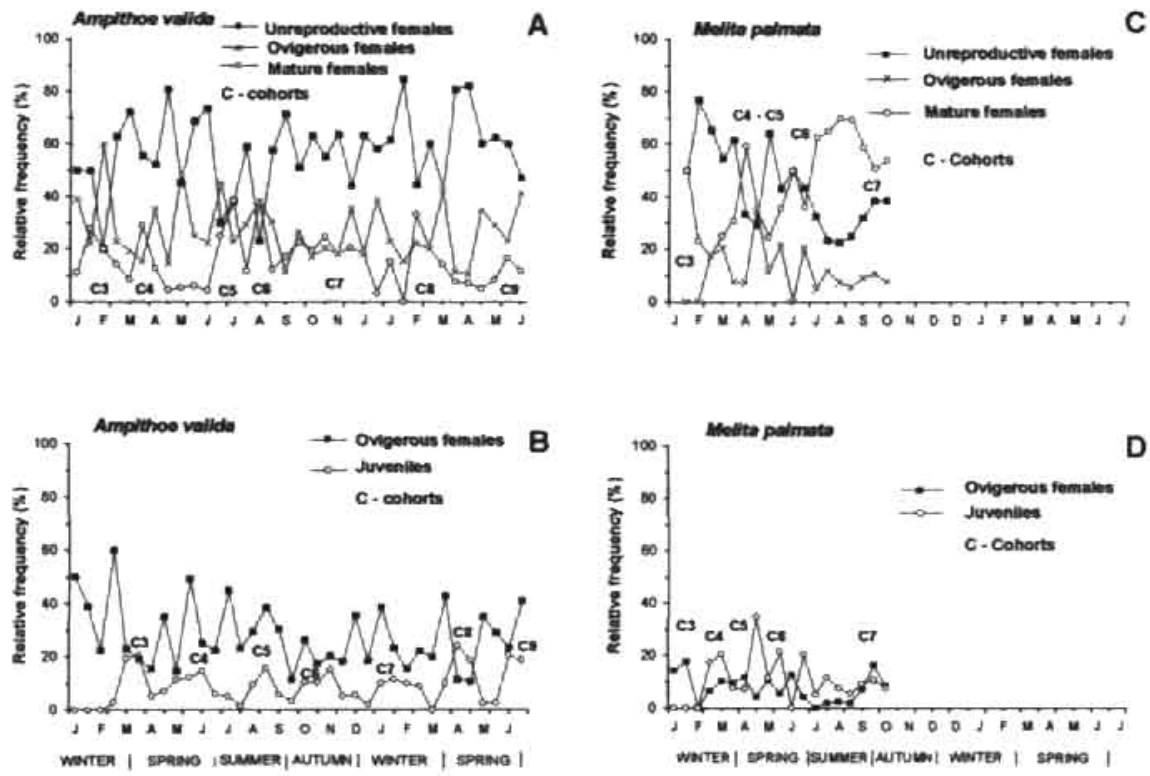

Fig. 4. Biological features of $A$. valida and $M$. palmata population. ( $A$ and $C$ ) Vanation of females in different physiological stages in relation to the fernale population; ( $B$ and D) Variation of ovigerous females in the total female population and of juveniles in the population.

Reproduction, sex-ratio, and fecundity

The A. valida and $M$. palmato populations were sexually active throughout the year in the south arm of the Mondego estuary. However, taking into consideration the percentage of ovigerous females over the total female population (Fig. 4), sexual activity was higher from late spring to late summer. The variation of the percentage of juveniles in the population was clearly related to increases in recruitment of both species.

In $A$. valida and $M$. palmato females were usually more abundant than males overall, and no significant seasonal changes of this pattern were observed (Fig. 5). The fecundity of females of similar size was quite variable, and, no correlation between the number of developing embryos and female size was found in any of the studied species. Measurements of eggs in different developmental stages (Table I) showed that, egg volume increase changes seasonally. For instance on A. valida an increase of $361 \%$ was estimated in summer, $452 \%$ in spring and $492 \%$ in autumn. It was also possible to recognise that for the same developing stage eggs' volume was greater in colder periods, while the average number of eggs per female was smaller (table I and 2). 

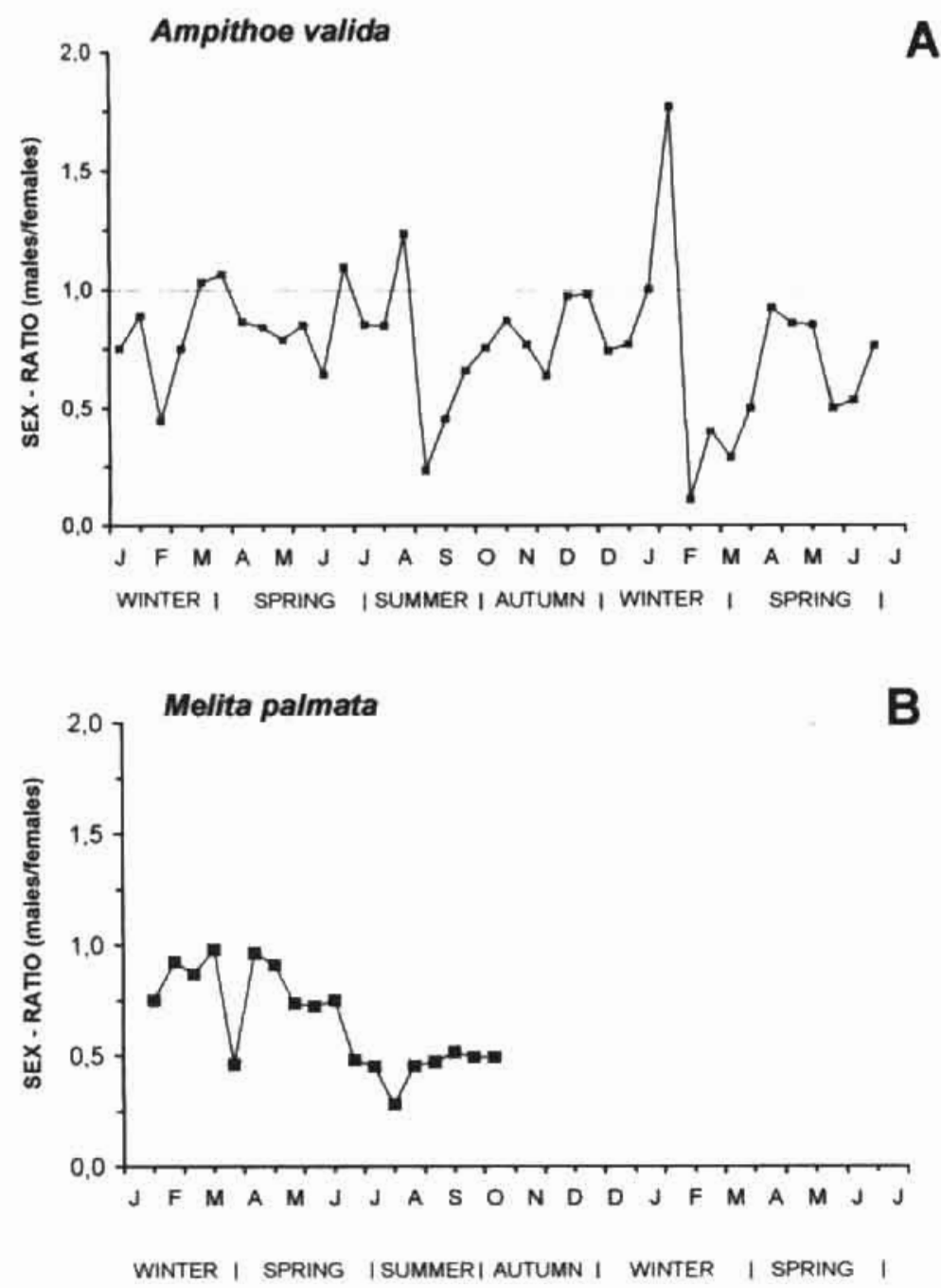

Fig. 5. Sex-ratio variation during the period of study. (A) Ampithoe valido. (B) Melito polmata.

464 Table I. Mean number (N) and volume (Vol) of eggs per female of Ampithoe valida, at development stages $A B, C . D$ and $E$, in the Mondego estuary.

\begin{tabular}{|c|c|c|c|c|c|c|c|c|}
\hline & \multicolumn{2}{|c|}{$\mathrm{AB}$} & \multicolumn{2}{c|}{$\mathrm{C}$} & \multicolumn{2}{|c|}{$\mathrm{D}$} & \multicolumn{2}{|c|}{$\mathrm{E}$} \\
\hline & $\mathrm{N}$ & $\begin{array}{c}\text { Vol } \\
\left(\mathrm{mm}^{3}\right)\end{array}$ & $\mathrm{N}$ & $\begin{array}{c}\mathrm{Vol} \\
\left(\mathrm{(m}^{3}\right)\end{array}$ & $\mathrm{N}$ & $\begin{array}{c}\text { Vol } \\
\left(\mathrm{mm}^{3}\right)\end{array}$ & $\mathrm{N}$ & $\begin{array}{c}\text { Vol } \\
\left(\mathrm{mmm}^{3}\right)\end{array}$ \\
\hline Winter & 18 & 0,205 & 12 & 0,218 & 16 & 0,384 & 7 & - \\
\hline Spring & 16 & 0,151 & 24 & 0,186 & 18 & 0,214 & 9 & 0,682 \\
\hline Summer & 11 & 0,155 & - & 0,170 & - & 0,167 & - & 0,56 \\
\hline Autumn & 6 & 0,218 & 11 & 0,232 & - & 0,233 & - & 1,073 \\
\hline
\end{tabular}


Table 2. Mean number ( $N$ ) and volume ( Vol) of eggs per female of Melita palmato, at development stages A, B, C. D and E, in the Mondego estuary.

\begin{tabular}{|c|c|c|c|c|c|c|c|c|c|c|}
\hline & \multicolumn{2}{|c|}{ A } & \multicolumn{2}{|c|}{ B } & \multicolumn{2}{|c|}{ C } & \multicolumn{2}{|c|}{ D } & \multicolumn{2}{|c|}{ E } \\
\hline & $\mathrm{N}$ & $\underset{\left(\mathrm{mm}^{3}\right)}{\mathrm{v}}$ & $\mathrm{N}$ & $\begin{array}{c}\mathrm{Vol} \\
\left(\mathrm{mm}^{\prime}\right)\end{array}$ & $N$ & $\begin{array}{c}\begin{array}{c}\text { Vol } \\
\left(\mathrm{mm}^{3}\right)\end{array} \\
\end{array}$ & $\mathrm{N}$ & $\begin{array}{c}\text { Vol } \\
\left(\mathrm{mm}^{2}\right)\end{array}$ & $\mathrm{N}$ & $\begin{array}{c}\mathrm{Vol} \\
\left(\mathrm{mm}^{\prime}\right)\end{array}$ \\
\hline Winter & 1,5 & 0,71 & 2,8 & 1,34 & - & - & 8 & 1,57 & 2,5 & 3,46 \\
\hline Spring & 1 & 0,60 & 4,7 & 0,97 & 3,5 & 1,35 & 3,3 & 1,99 & 4,25 & 2,24 \\
\hline Summer & 3 & 0,98 & 3,8 & 0,96 & 2 & 1,35 & 2,5 & 1,58 & 1,7 & 2,82 \\
\hline Autumn & - & - & - & - & 2,5 & 1,26 & 4,5 & 1,89 & 1 & 3,63 \\
\hline
\end{tabular}

The difference in time between peaks of eggs in the first stage of development (A) and the last one (E). provided us an estimation of the duration of the embryogenic development quite similar for both species (Fig.6). During spring and summer the embryogenic development was faster (30-45 days) than in autumn or winter (60 days).

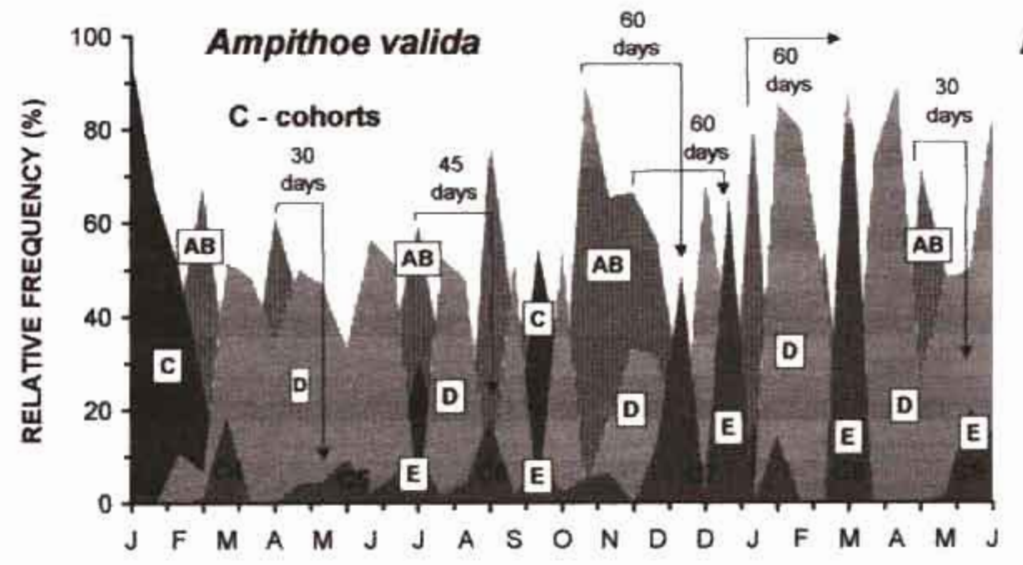

WINTER | SPRING | SUMMER | AUTUMN | WINTER | SPRING |

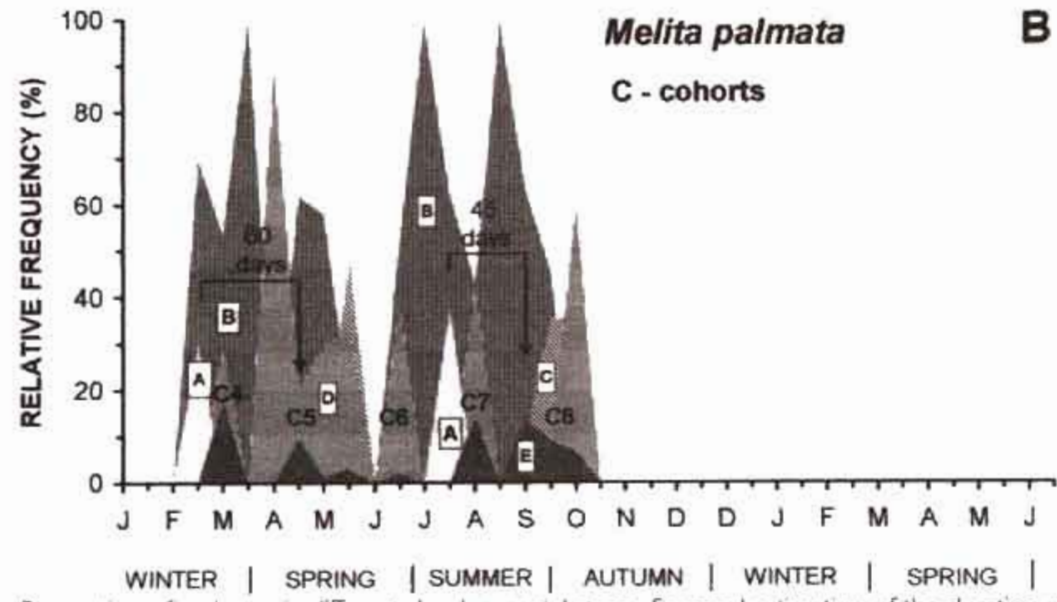

Fig. 6. Proportion of embryos in different developmental stages. Seasonal estimation of the duration of the embryogenic development. (A) Ampithoe valido: (B) Melito polmato. 
Growth and life span

Size frequency polymodal distributions were analysed for recognisable cohorts, allowing in first place to identify significant differences in the population structure on the Zostera beds and in the most eutrophicated area. As a pattern for these two species, Individuals reached larger dimensions at the most eutrophicated area in comparison with the other two areas ( $Z$ noltii meadows and intermediate eutrophicated areas). Nevertheless, in the first months the recruitment pattern was the same all along the eutrophication gradient. Following the algae crash both populations disappeared from the most eutrophicated area and cohorts tracking became only possible at the $Z$. nottii meadows. For instance, for $A$. valida in January of 1993 three cohorts were identified, and six new ones were recognised during the study period ( $\chi^{2}$ and $G$ not significant, $P \leq 0.05$ ). Minimum average $C_{1}$ of cohorts ranged from 0.327 (spring) to $0.397 \mathrm{~mm}$ (winter) corresponding to 2.946 and 3.606 $\mathrm{mm}$ of total length.

For both species growth was continuous through life (Fig. 7). Nevertheless, growth rates were higher during spring and summer and decreased during winter. Lower growth rates during winter were probably a function of lower temperatures and lower biomasses of macroalgae (food resources).

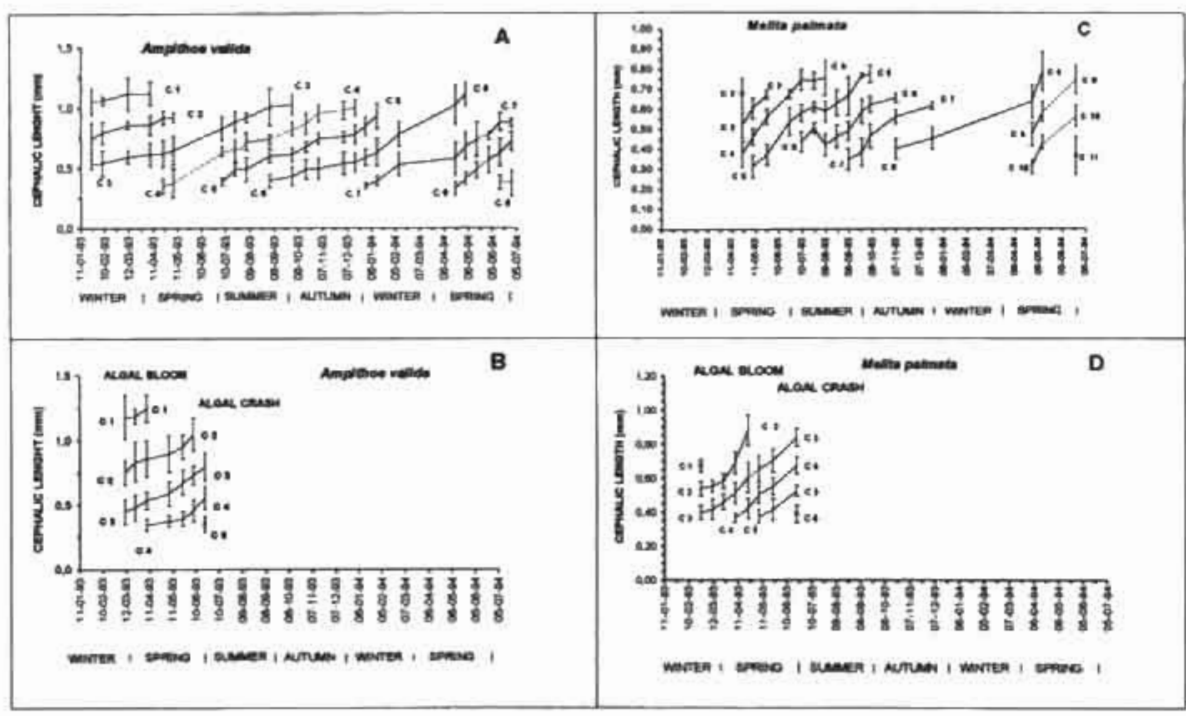

Fig. 7. Estimated growth (field growth data) of cohorts \pm standard deviation of Ampithoe volido and Melito paimoto. ( $A$ and C) Z nolti meadows; (B and D) Most eutrophicated area.

Life spans were estimated for A valida at $191 \pm 30$ to $238 \pm 15$ days for summer and spring cohorts and at $242 \pm 30$ days for the autumn cohort and for 
M. palmato at $120 \pm 30$ to $148 \pm 15$ days for summer and spring cohorts and at $182 \pm .30$ for the autumn cohort. Similarly, for both species the age at which females and males matured were lower in spring and summer cohorts than in the autumnwinter cohorts. Nevertheless, during the yearly cycle. males always reached maturity before females.

\section{Production estimates}

Length-weight relationships previously established (Pardal 1998, Pardal et al. 2000) were used in production estimates in the most eutrophicated area and in the $Z$. nolti meadows (Tables 3 and 4). Taking into account the whole period of study, results clearly showed that growth productivity $(P)$, elimination productivity $(E)$ and the relations $P / \bar{B}$ and $E / \bar{B}$ were much higher in the $Z$. nolti meadows. But in the most eutrophicated area during the algal bloom $\mathrm{P}, \mathrm{E}$ as well as population density, were clearly higher than in $Z$. noltii meadows (Tables 3 and 4).

Table 3. Production estimates for Ampithoe valido at $Z$ nolti meadows and at the most eutrophicated area taking into account different periods of time with different ecological conditions.

\begin{tabular}{|c|c|c|c|c|c|}
\hline & $\begin{array}{c}P \\
\left(\mathrm{gm}^{2} \text { time) }\right.\end{array}$ & $\underset{(\mathrm{Bm})}{\bar{B}}$ & $\mathrm{P} / \bar{B}$ & $\begin{array}{c}E \\
\left(\mathrm{~g} \mathrm{~m}^{\prime} \text { time }\right)\end{array}$ & $E / \bar{B}$ \\
\hline $\begin{array}{l}\text { Z. nolti (1 } 8 \text { months) } \\
\text { (January } 1993 \text { to June 1994) }\end{array}$ & 0.635 & 0.106 & 5.988 & 1.316 & 12.41 \\
\hline $\begin{array}{l}\text { Z. noltii (1 } 3 \text { months) } \\
\text { (January } 1993 \text { to February 1994) }\end{array}$ & 0.409 & 0.112 & 3.646 & 0.853 & 7.603 \\
\hline $\begin{array}{l}\text { Z. noltii ( } 13 \text { months) } \\
\text { (May } 1993 \text { to June 1994) }\end{array}$ & 0.531 & 0.092 & 5.756 & 0.921 & 9.972 \\
\hline $\begin{array}{l}\text { Z. nolti ( } 3 \text { months) } \\
\text { (April } 1993 \text { to June 1993) }\end{array}$ & 0.036 & 0.486 & 0.074 & 0.082 & 1.685 \\
\hline $\begin{array}{l}\text { Eutrophicated area ( } 3 \text { months) } \\
\text { (with a macroalgal bloom) } \\
\text { (April 1993 to June 1993) }\end{array}$ & 0.411 & 0.343 & 1.20 & 0.945 & 2.758 \\
\hline $\begin{array}{l}\text { Eutrophicated area ( } 4 \text { months) } \\
\text { (with a macroalgal bloom) } \\
\text { (March } 1993 \text { to June 1993) }\end{array}$ & 0.444 & 0.312 & 1.424 & 0.945 & 3.033 \\
\hline
\end{tabular}


Table 4. Production estimates for Melito palmato at $Z$. noltii meadows and at the most eutrophicated area taking into account different periods of time with different ecological conditions.

\begin{tabular}{|c|c|c|c|c|c|}
\hline & $\underset{\left.\left(g m^{2} \text { time }\right)^{\prime}\right)}{P}$ & $\begin{array}{c}\bar{B} \\
\left(\mathrm{~g} \mathrm{~m}^{2}\right)\end{array}$ & $\mathrm{P} / \overline{\mathrm{B}}$ & $\begin{array}{c}E \\
\left(\mathrm{gm} \mathrm{m}^{\prime} \text { time') }\right.\end{array}$ & $E / \bar{B}$ \\
\hline $\begin{array}{l}\text { Z. noltii (14,5 months) } \\
\text { (April 1993 to June 1994) }\end{array}$ & 0.473 & 0.063 & 7.561 & 0.767 & 12.26 \\
\hline $\begin{array}{l}\text { Z. noltii (13 months) } \\
\text { (June } 1993 \text { to June 1994) }\end{array}$ & 0.456 & 0.064 & 7.144 & 0.734 & 11.49 \\
\hline $\begin{array}{l}\text { Z nolti (2 months) } \\
\text { (April } 1993 \text { to June 1993) }\end{array}$ & 0.059 & 0.029 & 2.030 & 0.062 & 2.131 \\
\hline $\begin{array}{l}\text { Eutrophicated area ( } 2 \text { months) } \\
\text { (with a macroalgal bloom) } \\
\text { (April 1993 to June 1993) }\end{array}$ & 0.496 & 0.397 & 1.248 & 0.683 & 1.720 \\
\hline $\begin{array}{l}\text { Eutrophicated area ( } 4 \text { months) } \\
\text { (with a macroalgal bloom) } \\
\text { (March } 1993 \text { to June 1993) }\end{array}$ & 0.728 & 0.236 & 3.088 & 0.702 & 2.977 \\
\hline
\end{tabular}

\section{Discussion}

\section{Abundance}

For both species population density clearly changed along the eutrophication gradient as a result of the macroalgal annual dynamics, like observed before for Microdeutopus gryllotalpo (Drake and Arias 1995). In fact, in the most eutrophicated area, the occurrence of a macroalgal bloom in the first year prepared the conditions for the presence of large densities of A. valido and M. palmato. The algal crash, which acted as a catastrophic event (Marques et al. 1997) and the non occurrence of an algal

468 bloom in the second year had a strong effect on the population's density in the inner parts of the estuary. Consequently, since in the second spring (1994) there were no macroalgae habitats available, A. valida and M. polmata individuals seemed to occur only in the $Z$ noltii meadows.

During the macroalgae bloom the population densities of both species were much higher than in the $Z$. noltii meadows in the same period. This may be related to habitat protection against potential predators (crabs. fishes and birds) and food resources (Greeze 1968, Duffy and Hay 1991), since they can feed directly on the algae. Next, during the algae crash, when anoxic conditions occurred, the amphipods 
population suffered a sudden and drastic reduction. After the algae crash the amphipods population was never able to recover since no food resources were available. On the contrary, in the $Z$, noltui meadows both species increased in number after the algae crash. A possible movement of adult individuals inside the estuary moving to avoid the extreme conditions of anoxia, is the most probable explanation, together with new recruitments taking place in this area. It seems therefore that both species have a large potential for dispersion inside the estuary, avoiding as much as possible stressing situations caused by macroalgae blooms in early summer, It seems reasonable to conclude that in a certain extent the development of macroalgae biomass favours A. valida and M. polmato populations, but extensive blooms affecting the whole area of distribution of this species will determine its disappearance.

Reproduction, growth and life cycle

Data showed that females of both species almost always outnumbered males, which is a common feature in amphipod populations (Hastings 1981. Dauvin 1988a, 1988b, Marques and Nogueira 1991. Morrit and Stevenson 1993, Covi and Kneib 1995. Sudo and Azeta 1996).

In our case embryonic development was fast but showed seasonal variations. from 30 days in spring up to 60 days in autumn and winter. In colder months the developing embryos (in fewer number) present larger volumes, which allow to optimise chances of survivorship since they contain higher nutritive reserves. Such volume increase was higher than the one observed by Moore and Wong (1996). although they were similar to the ones calculated by Marques and Nogueira (1991) for Echinogammarus marinus. Moreover, in spring and summer sexual maturity was reached at smaller sizes in comparison with autumn cohorts, which agrees with previous observations on other amphipods (Moore 1991. Powell and Moore 1991. Sudo and Azeta 1996).

Summer and spring growth rates were much higher than during colder months. This was also observed for other amphipod species in temperate areas (Hasting 1981, Dauvin 1988a, 1988b, Franz 1989, Marques and Nogueira 1991. Uitto and Sarvala 1991. Drake and Arias 1995. Wilson Jr. and Parker 1996), and growth rates estimated by us were similar to other species at the same latitude (Ali and Salman 1987. Marques and Nogueira, 1991. Drake and Arias, 1995).

Like other amphipod species, A. valida and M. palmata are semi-annual with short-lived spring and summer generations and long-lived autumn and winter generations (Moore 1981. Powell and Moore 1991. Beare and Moore 1994, Sudo and Azeta 1996).

Both species appeared as $r$ strategists, with iteroparous females, multivoltine cycles, high individual fecundity and recruitment all over the year. This is the most common pattern in epifaunal species (van Dolah 1980) from physically controlled communities according to the stability-time theory (Sanders 1969). In environmental stressed systems like estuaries we should expect the evolution of opportunistic adaptive strategies to take place. 


\section{Production estimates}

Taking into account the whole period of study $P$ (growth productivity) and $E$ (elimination productivity) as well as $\bar{B}$ (standing stock) showed significantly higher values in the $Z$. noltii beds than in the most eutrophicated area. Nevertheless, this difference does not reflect the entire reality. In fact we must look carefully to the dynamics of the two areas. In the most eutrophicated area for a short period (during the macroalgae bloom) P.E as weil as $\bar{B}$ were higher than in the $Z$. noltii meadows. This means that during the macroalgae bloom the most eutrophicated area was clearly the preferential habitat for the Amphipods probably due to resources availability.

The results clearly suggest that A. valida and M. palmato population dynamics and spatial distribution may change as a function of environmental changes through adaptative behavioural mechanisms. Nevertheless, it appears that macroalgae may represent mainly a good additional resource for population with a stable habitat like $Z$. noltii beds. But the macroalgae mats by it self can not sustain stable populations of amphipods due to its own dynamics. A conclusion would be that the total replacement of $Z$. noltii by macroalgae mats would negatively affect this kind of grazers.

The present results suggest that these species may play a more important role in the trophic dynamics than we might expected from their standing stock biomass. As pointed out by Fredette and Dias (1986), our data show that in warm shallow marine habitats relatively low biomass of benthic invertebrates can result in large production estimates (Kalejta and Hockey 1991).

As a whole, in the Mondego estuary, although macroalgae seem to be favourable to amphipods populations, if we look to the following effects of the algae crash it is reasonable to conclude that more extensive blooms, affecting the whole area of distribution of the species will on the contrary have a strong negative impact and could imply its disappearance.

\section{Acknowledgements}

This paper was carried out in the scope of the WET-project (Wetland, Ecology and Technology), financed by the European Scientific TMR Program (ERB 406। PL 95-0832). The authors are indebted to all colleagues who assisted in field and laboratory work

Ali M.H. and Salman SD 1987. Growth and production of the amphipod Partycle bosrensis (Talindae) in the Shatt al-Arab region. Mar. Ecol. Prog. Ser 40: 231-238.

Allen KR. 1971. Relation between production and biomass. J. Fish. Res. Bd. Can. 28: 1573-1581.

Beare D.J. and Moore P.G. 1994. Observations on the biology of a rare britsh marine amphipod: Monoculodes gibbosus (Crustacea: Oedicerotidae). J. Mar. Biol. Assoc. U.K. 74: 193-201.

Birklund f. 1977. Biomass, growth and production of the amphipod Corophium insidiosum Crawiond, and preiminary notes on Corophium volutotor (Pallas). Ophelia 16:187.203.

Borowsky B. 1983. Reproductive behaviour of three tube building peracarid crustaceans: the amphipods Jossa fakcoto and Amprthoe valida and the tanaid Tanos covolinu. Mar. Biol. 77: 257.263. 
Bregazzi P. 1972 Life cycles and seasonal movements of Cheinmedon femoratus (Pfeffer) and Tryphoselio kerguelent (Miers) (Crustacea: Amphipoda). Br. Antarct. Surv. Bull. 30: 1-34.

Conlan K.E and Bousfield E.L. 1982. The Amphipod superfamily Corophiondea in the North-Eastern Pacific region, Family Amphithoudae Systematics and distributional Ecology. Nat Mus Canada Publ. Boil. Oceanog. 10:41-75.

Covi M.P. and Kneib R.T. 1995. Intertidal distribution, population dynamics and production of the amphipod Uhlorchestio spartinophilo in a Georgia, USA, salt marsh. Mar. Biol. 121:447.455.

Dauvin J.C. 1986. Dynamique de la population d'Abro prismatco (Mollusque, Bivalve) de la baie de Morlaix (Manche occidentale). Annis. Inst. Océanogr. Paris 62:1-12

Dauvin J.C. 1988a. Biologie, dynamique et production de populations de Crustacés Amphipodes de la Manche Occidentale. 1. Ampelisca tenucornis Lijeborg. J. Exp. Mar. Biol. Ecol. 1 18:55-84.

Dauvin LC. 19886. Life cycle dynamics and productivity of Crustacea-Amphipoda from the westem English Channel. 4. Ampelisca armoricana Bellan-Santini et Dausin. J. Exp. Mar. Bio.l Ecol. 123: 235-252.

Dijk G.M. Liere L. Admiraal W. Bannink. B.A. and Cappon 1.j. 1994. Present state of the water quality of European rivers and implications for management. Sci, Tot. envr, 145: 187-195

Drake Pand Arias A.M. 1995 Distnbution and production of Microdeutopus gryllotalpo (Amiphipoda Aondae) in a shallow coastal lagoon in the Bay of Cadiz. Spain. I. Crus. Biol, 15:454-465.

Duffy J.E. and Hay M.E. 1991. Food and shelter as determinants of food choice by an hertivorous marne amphipod. Ecology 72: 1286-1298.

Elliot J.M. 1977. Statistical analysis of samples of benthic invertebrates. Freshwater Biological Association, Scientific Publications.

Fish J.D, and Mills A 1979. The reproductive biology of Corophium volutotor and C arenorium (Crustacea Amphipoda). J. Mar. Biol. Assoc. U.K 59: 355-368

Findt M.R. Kamp-Nielsen L. Marques J.C., Pardal M.A. Bocci M.; Bendoricho G.: Nielsen S.N. and Jørgensen S.E. 1997. Description of the three shallow estuaries Mondego River (Portugal), Roskilde Fjord (Denmark) and the Lagoon of Venice (Italy). Ecol. Model. 102:17.31.

Franz D.R. 1989. Population density and demography of a fouling community amphipod.J. Exp. Mar. Biol. Ecol. 125:117.135.

Fredette T.1. and Diaz R 1986. Secondary production of Gammorus mucronatus Say (Amphipoda Gammaridae) in warm temperate estuarine habitats, York river,Virginia.J. Grust. Biol. 6: 729.741.

Gaschütz G. Pauly D. and Dand N. 1980. A versatile basic program for fitting weight and seasonally oscillating length growth data. Pelagic, Demersal and Shellfish Cttes, $23 p$

Goedmakers A. 1981. Population dynamics of three gammand species (Crustacea, Amphipoda) in a French chalk steam It: Standing crop. Bijdr Dierk (Contr Zool) 51 : 31-69.

Greeze 1.1. 1968. Feeding habits and food requirements of some amphipods in the Back Sea. Mar. Biol. 1:316-321

Hartog C. 1994. Suffocation of a littoral Zostera bed by Enteromorpho rodiota. Aquat. Bot 47:21-28.

Hastings M.H. 1981. The life cycle and productivity of an intertidal population of the amphipod Ampelisco brevicomis. Estuar. Coast. Shelf Sc. 12:665-677.

Hickel W. Mangeisdorf P, and Berg f. 1993. The human impact in the German Bight eutrophication during three decades (1962-1991) Helgolander wiss. Meeresunters 47: 243-263.

Hodgkon E.P and Hamiton B.H. 1993. Fertilizers and eutrophication in the souttwestern Australia Setting the scene. Fert Res 36: 95-103.

Kalejta B. and Hockey PA.R. 1991. Distribution. abundance and productivity of benthic invertebrates at the Berg River estuary, South Afnca. Estuar. Coast. Shelf Sci. 33: 175-191.

Lavery PS. Lukatelich RJ. and McComb A. I991. Changes in the biomass and species compostion of macroalgae in a eutrophic estuary Estuar. Coast. shelf Sci 33:1-22.

Lillebe A.I., Findt M.R. Pardal M.A. and Marques J.C. 1999. The effect of macrofaunia, merofauna and microfauna on the degradation of Spartina mantuma detritus from a salt marsh area. Acta Oecol, 20 (4) 289-304.

Lillebe A.L., Pardal M.A. Cardoso P. and Marques J.C. 2001. The effect of primary producers dyramics (macrophytes and macroalgae) on Hydrobra ulvoe population dynamics, life cycle and production, in the south arm of the Mondego estuary Aquatic ecology of the Mondego river basin. Global importance of local expenence. (This volume)

Marques J.C.and Nogueira A. 1991. Lfe cycle, population dynamics and production of Echinogommarus mannus (Leach) (Amphipoda) in the Mondego estuary (Pontugal). Oceanol, Acta 11:213-223. 
Marques J.C. Rodrigues LB. and Nogueira A.J.A. 1993a Intertidal macrobenthic communities structure in the Mondego estuary (Western Portugal): Reference situation, Vie Milieu 43: 177-187.

Marques J.C. Maranhão P. and Pardal M.A. 1993b. Human impact assessment on the subtidal macrobenthic community structure in the Mondego estuary. (Western Portugal). Estuar. Coast. Shelf Sci37: 403-419.

Marques J.C. Martins .I, Teles-Ferreira C. and Cruz S. 1994. Population dynamics, life history and producuon of Cyothura coninato (Krøyer) (Isopoda: Anthuridae) in the Mondego estuary, Portugal. f. Crust. Biol 14: 258-272.

Marques J.C., Pardal M.A., Nieisen S.N. and Jergensen S.E., 1997, Analysis of the properties of exergy and biodiversity along an estuanne gradient of eutrophication. Ecol. Model. 102: 155-167.

Martins L., Marques I.C., jorgensen S.E. and Nielsen S.N. 1997. Modelling the effects of green macroalgae blooms on the population dynamics of Cyothura connoto (Crustacea: isopoda) in an eutrophicated estuary. Ecol. Model. 102:33-53.

Martins L. Pardal M.A. Lillebø A.I. Flindt M.R and Marques I.C. 2001. Hydrodynamics as a major factor controlling the cecurrence of green macroalgae blooms in an eutrophic estuary. a case study. Est. Coast. Shelf Sci. 52: $165-177$

Moore P.G. 1981. The life histories of the amphipods Lembos websteri Bate and Corophum bonnellin Mine Edwards in Kelp holdfasts. J. Exp. Mar. Biol Ecol. 49: 1-50.

Moore P.G. and Wong Y.M. 1996. Observations on the life history of Orchomene nanus (Krøyer) (Amphipoda: Lysianassoidea) at Millport. Scotland as deduced from baited trapping f. Exp. Mar. Biol. Ecol. 195: 53-70.

Morritt D. and Stevenson T.D.1. 1993. Factors influencing breeding intiation in a beachflea Orchestud gommarellus (Pallas) (Crustacea Amphipoda), J. Exp. Mar. Biol. Ecol. 165: 191-208.

Pardal MA. Marques J.C. and Bellan G. 1993. Spatial distribution and seasonal variation of subtidal polychaete populations in the Mondego estuary (western Portugal), Cah. Biol, Mar. 34: 497-512

Pardal M.A. 1998. Impacto da eutrofizaçăo nas comunidades macrobentónicas do Braço Sul do estuário do Mondego (Portugal). Ph.D. Thesis, University of Coimbra, Portugal

Pardal MA., Marques J.C.. Metelo I., Lillebo Al. and Flindt M.R. 2000, Impact of eutrophication on the life cycle. population dynamics and production of Ampithoe valida (Amphipoda) along an estuarine spatial gradient (Mondego estuary. Portugal). Mar. Ecol. Prog Ser, 196; 207-219.

Pardal MA., Marques J.C. Ferreira S., Martuns 1, and Lillebo A.I. 2001, Life Cycle. biotogy and producuon of na estuanne isopod (Cyathura connata). Aquatic ecology of the Mondego nver basin. Global importance of local expenence. (This volume)

Powell $R$ and Moore PG. 1991. The breeding cycles of females of seven species of amphipod (Crustacea) from the Clyde sea I. nat . Hist. 25: 435-479.

Rafaelli D. Limia J. Hull S. and Pont S. 1991. Interactions between amphipod Corophium volutotor and macroalgal mats on estuarine mudflats. J. Mar, Biol. Assoc. U.K. 71, 899-908,

Rafaelli D. Raven J, and Poole L 1998. Ecological impact of green macroalgae blooms. Oceanogr. Mar. Biol. 36: 97.125 .

Sanders H.L 1969. Marine benthic diversity: a comparative study. Am. Nat. 102: 243-282.

Sheader M. 1978. Distribution and reproductive biology of Corophium insidiosum (Amphipoda) on the N.E coast of England. 1. Mar. Biol. Assoc. U.K 58: 585.596

Skadsheim A. 1982 The ecology of intertidal amphipods in the Osio fjord. The life cycles of Chaetogammanus morinus and C. stoerensis. Mar. Ecol. 3: 213-224.

Steele D.H and. Steele V.j 1969. The biology of Gammarus (Crustacea. Amphipoda) in the northwestern Atlantic !: Gommarus duebeni Lilj. Can. J. Zool. 47: 235-244.

472 Steele D. and Steele V.1. 1973. The biology of Gommorus (Crustacea. Amphipoda) in the northwestern Atantic. Vill The duration of embryonic development in five species at vanous temperatures. Can. . Zool. 51: $995-999$.

Sudo H. and Azeta M. 1996. Life history and production of the amphipod Byblis joponicus Dahl (Gammandea. Ampeliscidae) in a warm temperate zone habitat, Shijikj bay, Japan.J. Exp. Mar. Biol, Ecol, 198: 203-222.

Uitto A and Sarvala 1. 1991. Seasonal growth of the benthic amphipods Pontoporeia affinis and P. femorata in a baltic archipelago in relation to environmental factors. Mar. Biol. 11:237-246.

van Dolah R.F 1980. A comparison of reproductive patterns in epifaunal and infaunal gammaridean Amphipoda. Estuar: Coast. Shelf Sci. 2: 593-604.

Yeates IS. 1993. Soils and fertilizer use in southwestern Australia. Fert. Res. 36: 123-125.

Wilson Jr. W.H, and Parker K 1996. The Iffe history of the amphipod, Corophium volutotor: the effects of temperature and shorebird predation, J. Exp. Mar, Biol. Ecol. 196: 239-250. 

Série

Investigação

$\bullet$

Coimbra

Imprensa da Universidade

2002 